\title{
The economics of biofuels
}

\author{
President Obama's emphasis on energy policy gives a boost to the alternative fuel business in the USA
}

U S President Barack Obama is keen to tackle the related problems of America's massive oil consumption and global climate change. But, it was his predecessor, President George W. Bush - a former oilman no less - who hit the nail on the head in his 2006 State of the Union Address: "Keeping America competitive requires affordable energy. And here we have a serious problem: America is addicted to oil, which is often imported from unstable parts of the world" (Bush, 2006). Bush called on the USA to tackle its addiction problem-two years before the American public were to suffer the shock of more-than-US\$4-per-gallon petrol, and three years before the warning lights of a recession began flashing.

\section{...advocates for second- and third-generation biofuels- including hundreds of start-up companies - have been caught up in the environmental frenzy of Obamania...}

Meanwhile, President Obama is confronted with the deepest economic crisis since the Great Depression of the 1930s. At the same time he is promising acrossthe-board change in areas including healthcare, education, foreign policy, industry, the environment and energy security. Yet, as he told a Joint Session of Congress in February 2009, turning the country around "begins with energy." He said: "We know the country that harnesses the power of clean, renewable energy will lead the twenty-first century. And yet, it is China that has launched the largest effort in history to make their economy energy efficient. We invented solar technology, but we've fallen behind countries like Germany and Japan in producing it. New plug-in hybrids roll off our assembly lines, but they will run on batteries made in Korea" (Obama, 2009).

Obama maintained that his recovery plan would double the US supply of renewable energy over the next three years. "[T]o support that innovation, we will invest [\$15] billion a year to develop technologies like wind power and solar power; advanced biofuels, clean coal, and more fuel-efficient cars and trucks built right here in America." When he was a presidential candidate, he had already called for 60 billion gallons of biofuels to be produced each year by 2030 .

But, Obama's green advisor, Daniel Kammen of the University of California, Berkeley, has urged him to back away from the first-generation biofuels, warning that more greenhouses gases are emitted from cars fueled by ethanol than from those using regular gas (Harrabin, 2008).

7 here is growing momentum for secondgeneration fuels - that is, cellulosic ethanol from biomass, including switch grass and agricultural residues-and thirdgeneration biofuels that come from other sources such as algae. Indeed, advocates for second- and third-generation biofuelsincluding hundreds of start-up companieshave been caught up in the environmental frenzy of Obamania, which includes a stimulus package that they think will re-energize their efforts and create millions of new jobs, simultaneously eliminating oil imports from the Middle East and Venezuela.

"We like the signals that we're hearing from the Obama administration. They've clearly been promoting green energy and green jobs as one of the cornerstones of the sustainability stimulus recovery package," commented Landon Steele, Director of Program Management in the Biorefinery Group at Genencor (Palo Alto, CA, USA), which produces enzymes that break down cellulose into ethanol. "A first draft of the new Energy and Security Act of 2009 just came out, and it has some good provisions in it. They're very, very focused on reducing global warming and reducing greenhouse gases, and on programs to prepare workers to work in the green economy. I think that's fantastic." She also added that the biofuel community applauds the appointment of physicist Steven Chu - a Nobel Prize winner and an advocate of research into alternative fuels - as Secretary of the US Department of Energy.

Her colleagues in academic research are similarly delighted about this new-found support for alternative fuels. "The administration has been supportive from the environmental angle with the potential for the regulation of carbon," said Kelly Tiller, an agricultural economist and Director of External Operations for the University of Tennessee's Office of Bioenergy Programs (Knoxville, TN, USA). "From a national and energy security angle, there are some very supportive discussions. From a funding angle [...] the signals from the new administration are very positive, not only in the depth of support, but also the breadth."

However, James D. McMillan-a principal engineer and manager of Biochemical Refining Process's Research and Development at the US Department of Energy's National Renewable Energy Laboratory (Golden, CO, USA)-commented that Obama's policies are not altogether new. "I see basically a continuation and maybe an acceleration of those same policies that were in place [under President Bush] in terms of [improving] energy efficiency and [inventing] renewable energy technologies, in biofuels especially," he said.

n recent years, many big oil companies, which had flirted with renewable energy, have generally moved away from biofuels. Rex W. Tillerson, for exampleChairman and Chief Executive Officer of 
Exxon Mobil Corporation (Irving, TX, USA), the world's largest oil company-has dismissed ethanol as 'moonshine'. Shortly after Obama's election, he said: "In my view nothing has really changed. We don't oppose alternative energy sources. [...] But to hang the future of the country's energy on those alternatives alone belies the reality of their size and scale" (Mouawad, 2009).

Yet, British Petroleum (BP; London, UK), which advertises itself as "beyond petroleum", has invested US\$2.9 billion in renewable energy research, including wind power, solar power, carbon sequestration and biofuels, according to Tom Mueller, spokesman for BP America Inc. (Houston, TX, USA). He pointed out that his company pursues a three-pronged strategy on biofuels and will spend US\$500 million on research over the next decade. "[The first prong] is sugarcane; then there is transitional technology, which we refer to as advantaged molecules-bio-butanol fits into that category - and the third tier is future technology, which is the cellulosic biofuels," he said.

\section{The emphasis on second- generation biofuels that do not take away resources from other industries is a result of the criticism levelled at first- generation biofuels...}

BP has invested more than US\$100 million in and formed a partnership with the biotechnology firm Verenium Corp. (Cambridge, MA, USA), a developer of high-performance specialty enzymes for the production of nextgeneration cellulosic ethanol. Mueller said that Verenium is planning a commercialscale plant to produce 36 million gallons of cellulosic ethanol per year. "Our strategy is to stay away from food-related materials or even materials that have competitors in the marketplace," he commented. "Some companies are going after wood chips or wood pulp to create biofuels, but you're always going to be competing with the paper industry for those wood resources."

Other companies aim to provide biological alternatives to replace kerosene and diesel. Amyris Biotechnologies (Emeryville, CA, USA), for example, uses genetically modified yeast to convert plant material into diesel and jet fuel. The company has just shown that its renewable diesel works in standard diesel engines, and plans to bring it to the market in 2010, according to the company's website. Kinkaid Reiling, President and co-founder of Amyris, expects that their biodiesel will become competitive when oil reaches the price of US\$60-70 a barrel. Elsewhere, Choren Industries (Freiberg, Germany) pursues a different approach: the company has developed a three-step gasification process to convert biomass into synthetic fuel and has built its first commercial plant to produce diesel.

T he emphasis on second-generation biofuels that do not take away resources from other industries is a result of the criticism levelled at first-generation biofuels primarily ethanol made from corn or sugar cane. In 2007, Jan Ziegler, a United Nations expert on food issues, unleashed a firestorm when he described biofuels as a "crime against humanity" (Lederer, 2007) and argued that food shortages and rising prices threatened the lives of millions of poor people. "The disadvantage of the first-generation [biofuels] is that we can't produce enough fuel from food crops without compromising our food system and that's a huge issue," commented Steven Fales, agronomist and Associate Director of the Office of Biorenewables Programs at lowa State University (Ames, IA, USA). Yet, he clarified that, "[i]t's really a fairly convoluted story. The fact of the matter is that current biofuel production is not threatening anybody's food because we're not producing enough of it from these food crops. But, if we intend to follow the US government's plan to really ramp up biofuel production, then yes, we're going to have a problem. Because of this, the US Department of Energy and the US Department of Agriculture have said, 'Okay, we're going to put a cap on first-generation biofuels.'"

The apparently lower financial costs associated with biofuels are also difficult to assess properly. Tiller commented that biofuel companies often do not differentiate between current costs compared with projected costs. "What they generally give you is their projected cost with more mature technology [...] not necessarily for where they are right now. And one of the challenges is that they've not actually [produced biofuels] at a large commercial scale," she said. "Though something works very well at a small scale or in a lab or in one pond, it's not always a linear transition [to commercial production]." Tiller added that proponents often overlook fixed costs, citing the example of a company that claimed it could produce cellulosic ethanol for as little as US\$1 per gallon. "[l]t took me at least a year of digging and asking questions about this to realize that what they were talking about was, again, projected costs way in the future [...]. The other thing was that they did not include any capital costs. That was only their operating costs and didn't include any fixed costs. And the fixed costs per installed gallon of production doubled, tripled, quadrupled that number."

Moreover, Tiller thinks that third-generation biofuels might not be economical for years to come: "Advanced fuels from perhaps algae and some of the combined bioprocessing and some of those technologies that [...] we're working on now, those all look good, but they're 10 to 15 to 20 years out."

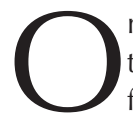
$n$ the consumer side of the equation, there is an increasing demand for biofuels, and not only from environmentally minded car drivers. Both the US car industry and the Obama administration - which had attempted to prop up General Motors (GM) and Chrysler with billions of dollars to fend off bankruptcyhave a role here. Mary Beth Stanek, GM's director of Environment and Energy Policy and Commercialization, oversees infrastructure and commercialization initiatives for biofuels, fuel cells and electric vehicle development at GM. She maintains that the US auto industry is ready for a future of biofuels. "Actually, you can fuel up today," she said. "The actual fuel itself is ethanol, whether it's from first-generation corn or second-generation cellulosic, or even, in the future, algae or some of the other thirdgeneration fuels. Ethanol is ethanol. It's the same molecule either way."

Stanek said that the existing car fleet could already use fuel containing up to $10 \%$ ethanol, and that flexible-fuel vehicles can use fuel with up to $85 \%$ ethanol. "We have more than 3.5 million flex-fuel vehicles on the road today that General Motors has produced in North America [...] And actually, if all those vehicles were filled with $85[\%$ ethanol fuel], we could use about 6.5 billion gallons of ethanol just in those flex-fuel vehicles." She added that oil companies aim to reach annual levels of 36 billion gallons of advanced biofuels by 2022, up from last year's target of 9 billion gallons.

Stanek is confident that it will be possible to both 'feed and fuel' without conflict: "there are actually 1.2 billion acres of abandoned land around the globe just lying, not doing anything," she said, pointing out that some of 


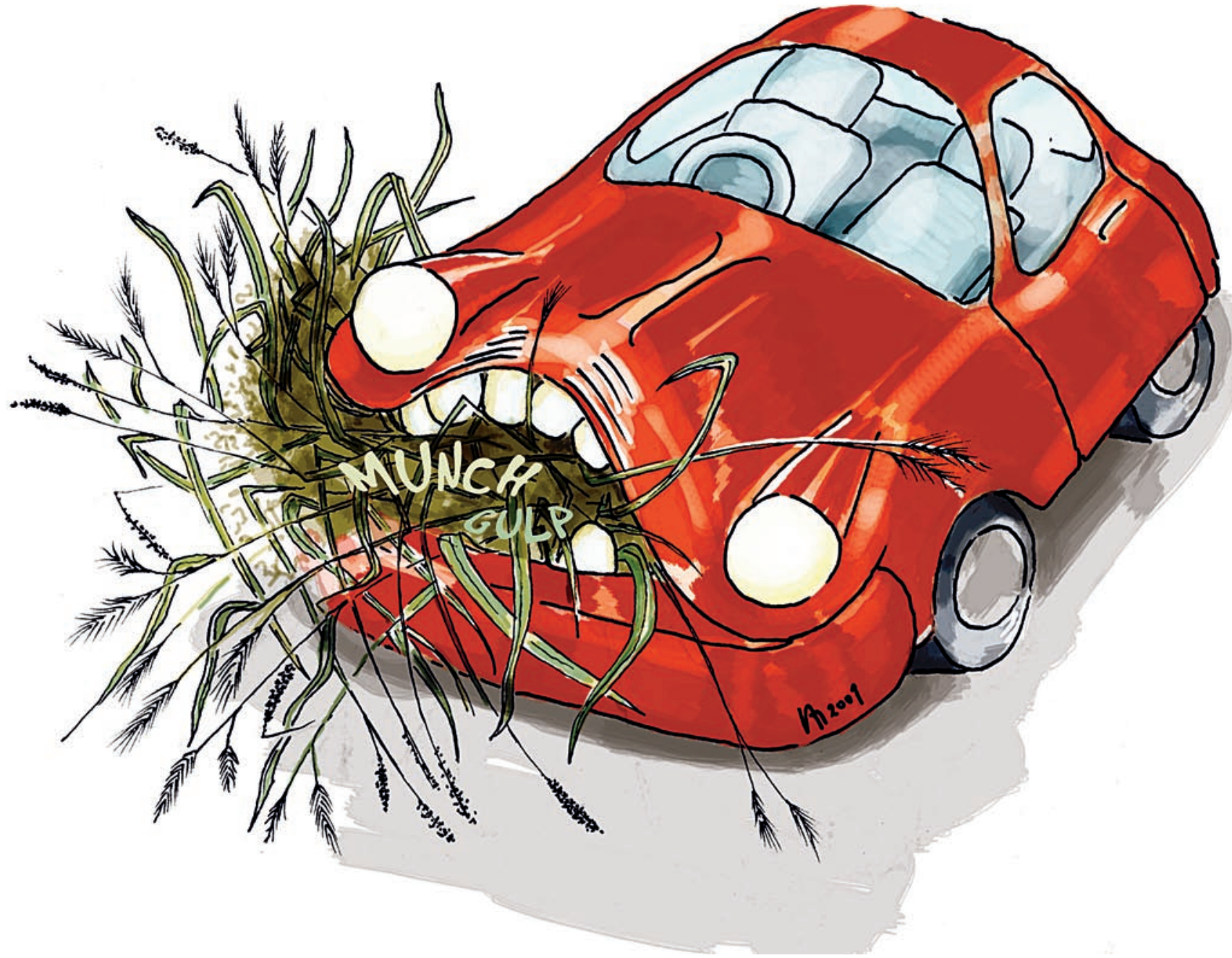

the land is now unused because the farmers could not compete against more productive areas, but that the land itself is still fertile. "I'm very optimistic. There isn't really an either/ or, but if done correctly and in a sustainable manner, we can have large portions of both."

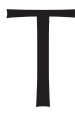

he huge question, therefore, is whether the American public are truly ready for change and will willingly give up their SUVs and other gas guzzlers to drive more efficient hybrid-powered or batterypowered cars that will be on the market within the next few years. "When gas prices were at [\$4] per gallon, we saw customers switch to smaller cars and we saw them decrease the number of miles that they drove. But now that prices are back down to [\$2] per gallon, people have forgotten about that and there are a lot of small cars sitting on the lot waiting for people to buy them," Stanek noted. "I think that if we're really focused on reducing greenhouse gas emissions here in the United States, and really intend to reduce our dependence on petroleum products, then improving the efficiency of vehicles is one key step to take. Low carbon fuels are another key step and, with both better efficiency and better fuels, we will be able to make a real, significant difference."

Within a few years, the production and supply of biofuels might well increase to a level that can replace at least some fossil fuel products, according to Tiller, who is also Chief Executive of Genera Energy, a newly formed University of Tennessee Research Foundation unit that is building a pilot cellulosic ethanol biorefinery in East Tennessee. She predicts that second-generation fuels will be competitive with ethanol within three years, but that they will always be a significant supplement to oil, rather than a wholesale replacement of it. "[Second-generation fuels are] expected to be cost competitive with the price of oil when oil is in the neighborhood of $\$ 60$ or $\$ 70$ per barrel. It depends [...] which reports you look at, but in that kind of range, it should be cost competitive within five years."

In the end, however, despite all the federal and state incentives that encourage the production and use of biofuels, market forces will have a more important role. "It's about the economics. If it is competitive and there are good, sound economic reasons, then these things will happen much sooner, with or without government policy," Tiller said. "For these fuels to be sustainable, they will need to be competitive economically without subsidies. Of course, getting them to that point [...] will certainly occur much faster with supportive policies."

\section{REFERENCES}

Bush GW (2006) State of the Union Address. The Washington Post, January 31

Harrabin R (2008) Obama's biofuels policy tension. $B B C$, July 28

Lederer E (2007) UN expert calls biofuel 'crime against humanity'. Associated Press, October 27

Mouawad J (2009) Oil giants loath to follow Obama's green lead. The New York Times, April 7

Obama B (2009) Address to Joint Session of Congress. Washington, DC, USA: The White House, February 24

\section{Howard Wolinsky}

doi:10.1038/embor.2009.121 